Article

\title{
Spirituality and Health in Pandemic Times: Lessons from the Ancient Wisdom
}

\author{
Alex Villas Boas $\mathbb{D}$ \\ CITER-Research Centre for Theology and Religious Studies, Universidade Católica Portuguesa, \\ 1649-023 Lisbon, Portugal; alexvboas@ft.lisboa.ucp.pt
}

Received: 1 October 2020; Accepted: 30 October 2020; Published: 4 November 2020

check for updates

\begin{abstract}
The goal of this paper is to analyze how the historical episode of the so-called Plague of Athens between the years 430 and $426 \mathrm{BC}$ seems to have been the first phenomenon classified as an epidemic by Hippocrates, and the historian Thucydides described its cultural, social, political and religious consequences. However, such a crisis generated the need for a new culture, and consequently a new theological mentality, as a cultural driver that made it possible to transform the Asclepiad Sanctuary of Kos into the first hospital in the West to integrate spirituality and science as ways to promote the healing of culture in order to achieve the ideal of health. The adopted method was a semantic analysis of the classic texts that help contextualize the Hippocratic view of the epidemic, spirituality, and health, and how these questions were received by Christianity at the time. The reception of this experience by Christianity, despite suffering some tension, also expands this Greek ideal and constitutes a true heritage of ancient wisdom that can be revisited in the time of the new pandemic, COVID-19. The perspective assumed here is interdisciplinary, putting in dialogue Theology and Health Sciences.
\end{abstract}

Keywords: spirituality and health; ancient epidemics; theology of health; COVID-19

\section{Introduction}

A pandemic is a contemporary concept that aims to better identify the degree of spread of a disease, relative to the concept of epidemic. According to its earliest definition by the World Health Organization, a pandemic is "an epidemic occurring worldwide, or over a very wide area, crossing international boundaries and usually affecting a large number of people" (Kelly 2011). Despite some records of the dissemination of diseases of pandemic proportions in the Ancient World, the technical concept used had always been epidemic. The concept derives from Hippocrates' clinical observations on the modus operandi of some diseases, especially the plague. In light of the new COVID-19 pandemic, this paper aims to reflect on how looking at the Greek accounts could provide a useful mirror for the contemporary pandemic situation. According to ancient wisdom, the epidemic's effect was not only a clinical issue; it also had political, social, and cultural repercussions. Consequently, it changes the way of thinking about religious and health issues. One of the most famous cases of this multifactorial repercussion in Western history is the episode that became known as the plague of Athens, in the 5th century BC.

In order to analyze how such impacts have changed what can be called a theology of health, which has great repercussions in the West, it would be helpful to reflect on the challenges of this contemporary pandemic, especially as concerns a shift in spirituality and health concepts. In matters of religion, pandemics can be a timely moment to overcome forms of theodicy, a religious way of thinking about divine justifications for human problems, frequently in opposition to science. Correspondingly, the shifting of a religious mindset, not uncommonly, may reconcile its connection with the sciences and might eventually broaden their respective perspectives. The reason for the ancient position is to 
think about life as a whole. It implies not only thinking about spirituality and health in epidemic times but every other field that threatens life, including politics. As part of a whole, health was a cultural issue for the Greeks, and for this very reason, pandemics demand much more than restoring physical health, but other cultural factors to develop shared strategies for coping with its various impacts.

The perspective assumed here is interdisciplinary, and therefore, the paper not only considers Classical and Theological Studies but also assumes that the challenge of the pandemic affects everyone: not only researchers and professionals in the health sector. This leads to notable points of intersection between pandemics in ancient times and the contemporary situation of COVID-19.

\section{Epidemic's Semantic Evolution in Hippocrates' Work}

The concept of epidemic has undergone a semantic evolution that highlights a new phenomenon in Greek culture. Mapping it has relevance considering the Greek root term "demos" indicated health's political dimensions. The word appears for the first time in Homer's first work, The Iliad, which is considered the start of Greek literature and is dated around the 12th century BC. Homer puts in Nestor's mouth the critique for those who love "war among his own people" (pólemos epidémios, Iliad IX.64) ${ }^{1}$, which is similar to the modern sense of civil war. At the end of The Iliad, Priam begs Achilles for the body of his son Hector and evokes his memory as a true hero who should be honored with a dignified funeral without desecrating him as a "false" hero, referring to those who "steal their own people" (epidémioi harpaktéres, Iliad XXIV.262) ${ }^{2}$. Likewise, in The Odyssey, the goddess Athens, disguised as Mentes, tells Telemachus she had visited the land of his father Odysseus, as she thought he was "among the people" (epidémion, Odissey I.194). Further on, Telemachus evokes the time that his father ruled Ithaca as "the man who was with the people" (anér epidémios Odissey I.234).

This meaning of the word epidemic, as something that happens "in the people" [epi demos], has crossed centuries of Greek literature in works by authors such as Plato (1921, cf. Laws VI.766c; Theaetetus 173e; Symposium 172c; Parmenides 126b), Aristotle (1984, cf. Politics II.1274a; V.1313b; Athenian Constitution 39), and Xenophon ([1910] 1970, cf. Cyropaedia VII.5), among others. Even Thucydides (460-397aC), who devotes chapter II of his History of the Peloponnesian War to the phenomenon of a rapid and great expansion of a disease in Athens, does not link epidemics to disease (Thucydides 1998, cf. The Peloponnesian War I.136. 3) ${ }^{3}$. Aristophanes, a contemporary of Thucydides, in his play Peace, directed at those responsible for the Peloponnesian War, resumes the Homeric idea: whoever promotes a civil war (polemós epidemia) does not love their country or their people (Aristophanes 1907, cf. Eiréne 1096-1098). Sophocles uses epidemos when talking about Oedipus' reputation among the people ${ }^{4}$. In addition, it is associated with a "rumor" that spread widely to many [polis] ${ }^{5}$ (Sophocles 1912, cf. Oedipus Tyrannus 494; 786).

The epi demos significance only went through a slight alteration in the time of the Roman Empire when it started to be used to mean "permanence or stay in a strange land", as found in the work Meditations or For yourself [Tà eis heauton] (Aurelius 1908, cf. Ad Se Ipsum II.17) by the Emperor Marcus Aurelius (121-180 AD). In biblical literature, in the Acts book of Acts, the word is used at the Feast of Pentecost (translated by the Vulgate by advenae romani) as the "visitors from Rome" in Jerusalem (epidemountes, cf. Acts 9,1-19). Eusebius of Caesarea, in the 4th century, uses the term regarding the advent of the God-man (theón epidemésen) to restore the dignity of life (Eusebius of Caesarea 1926-1932, cf. The Ecclesiastical History I.2). Basil, also from Caesarea and a contemporary of Eusebius, uses the

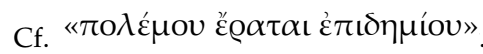

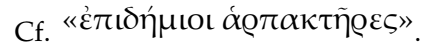

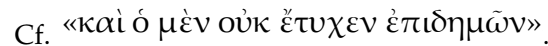

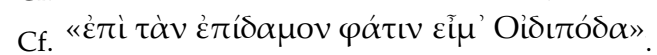

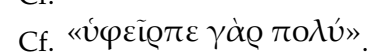


term "stay", in the theological sense when mentioning the "sojourn of the Lord in the flesh" (Kiriou he en sarki epidemía) in his letters (Basil of Caesarea 1926, cf. Letters 261; 37; 364).

As can be seen, epidemic is commonly used as a political concept evoking a form of presence and leadership in people's lives, as well as involvement in civil wars, public reputation, and foreign relations. This is precisely the context that Hippocrates $(460 \mathrm{aC}-370 \mathrm{aC})$ applied to the medical meaning of epidemic. The Hippocratic taxonomy used for disease is the Greek word nosos and could be classified as "acute" (oxeíes) or "chronic" (chróneis), namely pleurisy, pneumonia, phrenitis, lethargy, etc. For diseases such as plague or pest, the words loimós and loimódeos nousos are used as a kind of general pestilential form. However, for what will be further referred to as epidemic, Hippocrates adds a note as "diseases that affect the people together and at the same time" (koinos epidemése) (Peri diaites oxeon 2$)^{6}$.

Hippocrates' work entitled Epidemics consists of seven books, yet Books I and III are considered the most authentic (Cairus and Ribeiro 2005; Jones 1868). Book I expands epidemos' meaning toward public health, as a "disease on the people" (cf. nosema epídemon, Epidemics 1. 3. 14) features a set of symptoms, such as epidemic fever (pyretós epédemésen) ${ }^{8}$, being specific to an epidemic disease (epidemésanta nosémata, cf. Epidemics 3.2.3; 3.2.12) ${ }^{9}$.

In so doing, the Hippocratic book Epidemics introduces at least two new meanings to the Greek word epidemos. On one side, the term suggests the application of a political category conceiving of a public problem-that is to say, it concerns the people's disease, translated to Latin as De morbis popularibus. On the other side, epidemic comes to be used in a clinical sense regarding the Hippocratic study of diseases that threaten public health. Until the emergence of these early epidemic events, the physician of Kos alludes to stable public health (anosoi) considering the individual regimens applied (Epidemics 1.3.14) ${ }^{10}$. After the epidemic phenomenon, with an investigative intention to discover the sequences of symptoms and causes of success and failure of nature to expel the disease, Hippocrates describes forty-two cases, including names, living conditions, and addresses. Almost $60 \%$ of the cases resulted in death. The new use of epidemos takes place in the face of the new challenge of the disease, which is no longer happening in an individual sphere but with the potential to reach all people and comes from elsewhere, spreading on a large scale, requiring not only medical techniques (tekné) but cooperation between doctors and patients in the face of illness.

The first lesson to be drawn from Hippocrates' conclusions about the epidemic phenomenon is the Hippocratic principle of treatment involving a cooperative relationship between doctor and patient. This relationship is extended between the medical community and society, since the epidemic is a city disease (koinos epidemios). A parallel with modern epidemics could be thought of as national diseases, affecting the entire social body. In the case of the new COVID-19, it goes further, affecting all nations, thus constituting an international body and making working in unity fundamental to overcoming it. Nevertheless, the porosity of borders could mean that the irresponsibility of a single member can be lethal to the entire body, requiring greater international pressure in the face of any one country's negligence.

\section{Thucydides' Plague of Athens View}

Hippocrates was the first author to see the epidemic as a city disease, therefore a public health problem, and consequently a political one. However, it is Thucydides, the Athenian historian, who most

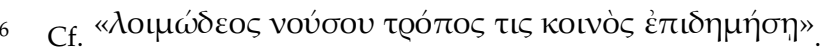

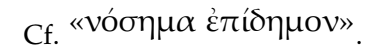

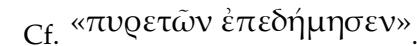

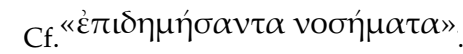

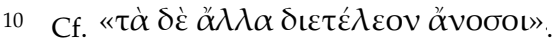


explores the epidemic's political effects. Thucydides' view of the so-called Plague of Athens resembles the same event described by the physician from Kos. There is a possibility that both authors are talking about the same event (The Peloponnesian War I. 2; Epidemics 3. 2. 3; 3. 2. 12) as similarities are found in the descriptive writing style of both, and even Hippocrates' methods may have influenced Thucydides. The historian has described Athenian society as an infected body, using the disease's etiological method from the places it reached, the period of time, and its symptoms (II. 47-60; III. 87).

In fact, Hippocratic medicine and the search for a healthy human being constitute the "cultural force" that initiates the Greeks' basic concept of paideia (Jaeger 2013), first establishing a relationship between culture and nature to achieve ideal health. In the book On Human Nature, part of the Corpus hippocraticum, health is the result of balance (homeostasis) that keeps the body as a whole functioning (Peri physis antropoi, 4). In the book, The Diet, balance is described as all elements in "mutual equality" (Peri diaites oxeon 69) as a condition for health, achieved through a good diet and physical activities (Peri diaites oxeon 69). In turn, disease is understood as an effect of the lack or excess of one of these elements.

The Hippocratic method of medical art (tekné) consists of seeing health based on the clinical practice of empirical data observation. Hippocratic homeostasis converges the philosophical and political ideal in Greece in the 5th century BC, of having "nothing in excess" (medén agan), implying the political balance of powers in the Athenian democratic system.

Thucydides seems to apply such a method (The Peloponnesian War II.49.1; 6; Epidemics I, 5; 26) to what he understands to be the Athenian political disease, regarding the form of excess (hybris) of greed, the pleonexia, in some oligarchs who think more about their own enrichment than about the people. Athens was internally disintegrated by this oligarchic hybris, even more than the plague, and externally, by the war that lasted from 431 to 404 BC, the date of the last battle, with the Spartans emerging victorious and resulting in the imposition of tyrannical rule and the death of the city's democratic regime.

Thucydides describes Pericles' attempt to call for assembly during Athens' political effort to prevent the fragmentation of political forces, and the consequent destruction of the regime with a metaphor of the unification of the body's forces (The Peloponnesian War II.60). Even though the epidemic plague of Athens revealed the political plague of oligarchic greed in a democratic regime, its two major symptoms had already taken over the city's entire social body. The first was anomia, a disbelief in nomos, the political and social institutions of the polis, as well in the divine law, given the social chaos that had set in:

"Nor was this the only form of lawless extravagance which owed its origin to the plague. Men now coolly ventured on what they had formerly done in a corner, and not just as they pleased, seeing the rapid transitions produced by persons in prosperity suddenly dying and those who before had nothing succeeding to their property. So, they resolved to spend quickly and enjoy themselves, regarding their lives and riches as alike things of a day. [ ... ] Fear of gods or law of man, there was none to restrain them. As for the first, they judged it to be just the same whether they worshipped them or not, as they saw all alike perishing; and for the last, no one expected to live to be brought to trial for his offences, but each felt that a far severer sentence had been already passed upon them all and hung ever over their heads, and before this fell it was only reasonable to enjoy life a little". (II.53.1-2.4)

The second fatal symptom was athimia, the absence of timós, the vital force that impels the hero to face challenges, so the population begins to suffer from despair and lack of resilience:

"By far the most terrible feature in the malady was the athimia which ensued when anyone felt himself sickening, for the despair into which they instantly fell took away their power of resistance, and left them a much easier prey to the disorder; besides which, there was the awful spectacle of men dying like sheep, through having caught the infection in nursing each other. This caused the greatest mortality". (II. 51.4) 
Thucydides did not exactly have a political prognosis for Athens. Even doctors were not enough to face the epidemic, as they were "the ones who died the most" due to the risk of exposure to the disease (II, 47.4). Nevertheless, the purpose of his description was to bequeath to future generations the democratic weaknesses, mainly the hybris of greed (pleonexia) or the hybris of love of self-honor (phyllotymia) exposed by bad politicians and evident in the face of the pandemic episode (II, 48.3). Thucydides even mentions a side effect, the insufficiency of the 5th century BC Greek religious mentality. In his words:

"Supplications in the temples, divinations, and so forth were found equally futile, till the overwhelming nature of the disaster at last put a stop to them altogether". (II. 47.4)

The plague, or the pest (loimós), was considered, until that point, a divine punishment of men's hybris, as it is found first in The Iliad (I, 59-67) with this idea reaching the Athenian democracy in golden times, as represented in the play of Sophocles, Oedipus Tyrannus (Oedipus, the king v. 22-43). In Thucydides, neither the cause of the plague nor the anomie situation of society is divine but results from the greed of a few and the lack of politicians who acted as doctors for their people.

The theology of the divine punishment of hybris (moira) had been rejected for its insufficiency to respond to this phenomenon; it was a disease that was "above the rationality" (kreissou logou) of the time. Thucydides tries to describe the phenomenon so future generations can find the culture cure: a change in mentality to face the weaknesses of democracy revealed by the plague (II. 52.3).

Thucydides also offers a second lesson that is useful for the contemporary moment of COVID-19. In such times, political unity is necessary for the nation's health. The absence of political leadership that puts the people first, instead of the oligarchic interests, leads society to a profound discrediting of institutions (anomie). Similarly, the lack of perspective and the inability to mobilize the nation toward the noble humanitarian ideals, meaning the capability of promoting solidarity and resilience in facing the disease, leads the population to despair and passionately irrational attitudes, such as war. Once in this scenario, the division of the people is accentuated, the credibility of democratic institutions is weakened, and opportunists may appear with the pretension of being saviors of the people. From Thucydides' perspective, these epidemic moments serve to reveal the politicians who are in favor of people and the populists who take advantage of people for their oligarchic interests. Another lesson is how these moments cause profound changes in religious mentality, specifically the crisis regarding the attempts of theodicy to offer divine justifications for human and social problems.

\section{From the Asclepius Sanctuaries to the School of Kos}

Thucydides' reports on Athens' religious decline do not coincide with the religious decline of all of Greece. The historian points specifically to the Athenian crisis of civic religion. In this case, there was a crisis of theodicy, the divine justifications for historical facts. Theodicy is a structure for punishment or even a kind of divine mathematics that aims to extract good things from bad things and is especially useful to shield political groups from rational criticism. It is common throughout the history of religions for major natural catastrophes or major wars to implode this type of theology in culture and society. Consequently, it weakens the power maintained by those ruling by this type of belief. The main reason is connected to the abeyance of deities who are supposed to help people deal with despair in the face of chaos, and thus initiate, on the one hand, different types of atheism, and on the other, the emergence of new theological perspectives.

Thus, despite the emergence of atheism in relation to the civic deities in Athens, there was also the emergence of new ways of thinking about religious issues, and therefore, a new spirituality arising from the challenge of facing the epidemic. This new phase in Greek religious culture was inaugurated from the Asclepiads Shrines, especially the Kos Shrine, establishing a fundamental role in the relationship between spirituality and health. Thucydides probably did not see the Asclepiads temple's transformation into real Antiquity hospitals due to the ostracism he suffered in Athens and the fact of his death in approximately $400 \mathrm{BC}$. 
Asclepiads formed a kind of religious community of physician "priests" who passed on their doctrine in priestly families, from father to son, and at some point, it was also passed on to non-family members (Gramaticos and Diamantis 2008). Such priests lived in shrines known as Asclepeion, which is dedicated to the deities of healing. These sanctuaries and Asclepius' cult began in the 4th century BC and lasted until the 4th century AD, with the Goths' invasion of Greece. Athens' decline, caused not only by the epidemic but also by the Peloponnesian war, increased hunger, lack of hygiene, and the scaling up of poor public health. In this context, reclusive religious practices grew in society, with people seeking peace and salvation for their immortal soul, as in the rise of orphism, which is responsible for influencing thinkers such as Pythagoras and Empedocles, or even the arise of Epicurism (Koch 2012, p. 17). Then again, the Asclepius sanctuaries also achieved great importance and expanded, as their religious cults included traditional healing practices.

The first Asclepeion was built in Athens and did not escape the anomia and athímia of the epidemic and the political chaos it produced. However, from the 5th to the 3rd century BC, at least ten other sanctuaries were built in Greece, namely: Corinth, Messene, Pergamum, Kos, Agrigento, Paros, Delos, Velia, and Epidaurus, the largest and most famous Asclepiad sanctuary, located in the Peloponnese, but outside the city borders in order to offer better health conditions. At Epidaurus, it is possible to find inscriptions with the records of cures experienced by pilgrims as healings (iamata) of Apollo and Asklepius. Among the pilgrims' testimonies of miracles, there is the healing of prolonged pregnancies, paralyzed limbs, blindness, gallstones, baldness, dropsy, worms, lice, headache, pus, sterility, tumors, abscesses, and various other types of illnesses today called mental illness (Dillon 1994, pp. 244-48). There were pilgrims from all over Greece in the Asclepiad sanctuaries, and the most famous one came to be recognized as Panhellenic. The Asclepiads sanctuaries were a huge complex of buildings that contained, in addition to the Temple of prayers, spas for medicinal baths, an amphitheater, a library, a guest house, and a gym for physical exercise. The largest one was Epidaurus, measuring 1398 hectares, which is an amphitheater with a capacity for 14,000 spectators and a monumental sports complex able to host what became known as Asklepieia, the Asclepian Games of Epidaurus, every 4 years. The temple administration had a sophisticated economy, with enough resources to create and maintain itself, generated mainly by donations from those who had been cured, indicating the positive reputation of the asclepiads (Burford 1969). In Pergamon's Asclepeion, there was the invocation of Asclepius Soter, who is considered a savior god given his importance in Greek society (Koch 2012, pp. 12-29). All the facts above show how Asclepiad spirituality was able to face the religious crisis initiated by the plague of Athens and its socio-political context. Furthermore, between the crisis of civic religion in Athens and the growth of the Asclepiads Sanctuaries lies the role of Hippocrates, the most famous asclepiad, and the Sanctuary of Kos, the second most famous Asclepeion. If the Epidaurus Sanctuary is famous for its size, Kos is famous for its new healing practices, which became known as medicine.

There are traditionally two hermeneutics from the School of Kos. One is of discontinuity in the Enlightenment trend, and it is intended to dissociate Hippocrates' relationship with the sanctuaries of Asclepius: an attempt to sever any relationship between reason and religion. Second, there is also the hermeneutics of continuity, concerning the medicine developed by Hippocrates, which is also situated in a new religious vision, a spirituality open to science, which refutes theodicy. The testimony of some of Hippocrates' contemporaries corroborates the hermeneutics of continuity. Plato, for example, identifies himself as being "of the asclepiads" (Pheadrus 270c; Protagoras 311b). Aristophanes talks about an oath from the Hippocratic community (sinoikia) in one of his plays from 411 BC (Thesmophoriazusae 274). The main source is the famous Hippocratic Oath in which the deities worshiped at the Asclepiad sanctuary are listed. Throughout Western history, the Hippocratic oath has always endured attempts to eliminate the mention of these deities worshiped in the Asclepeion. In the 6th century, there was a Jewish version of the Hippocratic Oath that is known as the oath of Asaph, Ben Berachyahu (Rosner and Muntner 1965, pp. 317-20), and in the 11th century, there was a Christian adaptation (Veatch 2000, 
p. 28; Verhey 1984, pp. 151-81) ${ }^{11}$. If Jews and Christians have tried to make a monotheistic version of the Hippocratic oath to eliminate the asclepiads deities, the Enlightenment adherents did the same by eliminating them in the name of a non-religious version. Even the Enlightenment was not able to reach a consensus on the opinion of Hippocrates being an atheist, as suggested by the encyclopaedist Diderot in his entry dedicated to the physician of Kos (Diderot 2020).

The maintenance of the deities in the Hippocratic Oath tracked between the refusal of the mystic religion's soul therapies and the embryonic elements of a spirituality that seeks the principles of understanding life through rational myths. It leads toward the origin of a new theology of health present in Greek myths, and of Hippocratic medicine, unifying the asclepiad wisdom with Ionian philosophy, in the Asclepeion of Kos.

\subsection{Theology of Healing Myths and the Hippocratic Oath}

The transformation of Asclepiads Temples into Antiquity Hospitals lies in the combination of science and spirituality. The first element concerns the influence of so-called Ionian science, and the second one concerns a mode of interpreting Greek myths.

Similar to many other great authors of antiquity, Hippocrates' life is a mix of reliable information and legends. In the 10th century AD Byzantine encyclopaedia called Suda, Hippocrates appears as a disciple of Democritus of Abdera (460-370 BC) after treating the philosopher's health. He would have learned the theory of atoms with him and applied it to the idea of the four humors: blood, phlegm, yellow, and black bile (Gramaticos and Diamantis 2008, p. 3). Others prefer to relate Hippocrates' theory of four elements (cold, dry, hot, liquid) with Empedocles' (494-434 BC) four elements (fire, water, air, earth) forming the structure of the world (Yapijakis 2009). Either way, Hippocrates seems to have had contact with Ionian science, undertaken by the so-called pre-Socratic philosophers on the work of observing nature (theoria). It supports his belief in nature's ability to recover, as well as guides his analysis in looking for the disease's natural causes.

The second element concerns a possible theology of health that underlies the relationship between spirituality and medical science in the Asclepiads sanctuaries. Starting from the hermeneutics of continuity, Hippocrates is certainly the most famous asclepiad in Ancient Greece. The construction of the temple of Kos started around 357 BC; however, the cult of Asclepius on the Island of Kos dates back to the presence of the Dorians around the 14th century BC, and in the time of Hippocrates, there was already an altar dedicated to Asclepian deities (Walton 1894). The main documentary source on healing theology is the Hippocratic Oath. It reveals not only the main deities of the Asclepiads Shrines but also the theology contained in their myths. However, it is opportune to understand the dynamics of the myth's interpretation in Greek religious culture to better situate the oath.

To take an oath to a divinity to exercise a trade or activity was considered a profoundly serious matter. Athletes, coaches, and judges, for example, took an oath in front of a scary statue of Zeus holding two thunderbolts, promising not to break the rules at the Olympic Games boulaterion, an assembly house for local legislatures, situated inside the sacred enclosure of the Altis, a sacred grove south of the temple of Zeus. Breaking an oath was not only a criminal offense but a serious offense to the gods (Pafsaniou 1898, Description of Greece 5.24.11 solar A). In ancient Greek religion, there was no doctrinal normativity, and this made possible alternative hermeneutics of myths. The unity of Greek paideia in the religious sphere takes place amid a "theology of diversity" consisting of a plurality of religious and theological expressions (Osborne 2015, p. 12).

At least two major hermeneutical lines can be identified in the theological evolution of myths in Classical Greece. The first is the persistent criticism of theodicies. Homeric literature (1200-800 BC) itself involves a criticism of theodicy. For example, in The Iliad, the first Homeric work (Homer 2012a),

11 The text can be found in the Vatican Library (Urbinus 64mss). Available at University of Minnesota. cf. <http: //www1.umn.edu/phrm/oaths/oath3.html>. 
everything happens according to the will of the gods, and especially the will of Zeus (Iliad I, 1-5). The human being is a mere plaything in the gods' hands. However, in The Odyssey, the second Homeric work (Homer 2012b), there are some changes in the posture of mortals blaming gods for their suffering and madness (Odyssey I, 32-34). Even Ulysses faces the supposed will of the gods to return home with the only divine mediation between him and Zeus being Athena, the goddess of wisdom. In this case, there is a new perspective about the same myths, a growing intimacy between the hero and the mediating divinity, a kind of philo-athena itinerancy, where spirituality is oriented toward the search for wisdom. A principle of philo-sophia that guides the hero Hesiod's choices about a century later involves the refusal of theodicy with the struggle for justice (diké) as a major theme in his poetry (Erga kai Hemerai, 1-10), and it influences the understanding of a poet as a prophet, especially of tragic authors. However, despite the hermeneutical advance, tragic theology is a product of Athenian democracy, and its political crisis engenders the need for a new theology. In the tragedy's theology, the gods punish human hybris as a means of maintaining political equality between the citizens; however, with weakened democratic institutions, deep faith in justice had been shaken. This theological vacuum was assumed by the Stoics in the fourth century BC. For the theological hermeneutics of the Stoics, the myth holds a wisdom that must be interpreted rationally (logos) to discover the universal laws of human conduct and conscience through empirical investigation. Therefore, the Stoic seeks to follow God, the universal reason that governs all things, to follow the human reason that participates in universal reason, and thus, to follow nature. Lucius Annaeus Cornutus (20 to $65 \mathrm{AD}$ ) summarizes the Stoic exegesis of rationally interpreting myths and shows how poetry (myth) for the Stoic, more than theoretical debate, constitutes itself as the most appropriate discourse to understand divine nature. After acknowledging this nature, it must be translated into rational principles. So, the myth of Poseidon (water) comes to be thought of as a fertility principle; the myth of Demeter (earth) comes to be thought of as a principle of stability; the myths of Apollo and Artemis (fire) come to be thought of as a proximity principle, since fire unites everything, and the myth of Hades (air) comes to be thought of as a principle of purpose (eschaton). In the Stoics, there is a philosophical appreciation of myths through allegory by extracting intuitive wisdom from the ancients (Cornutus 2018, cf. Theologiae Graecae compendium 22-35.3). For them, the interpretation of myths is an askésis, a spiritual exercise which is not in contradiction to reason (Hadot 2014).

The second major theological hermeneutics in the Classic Greek is the role of myth, or more precisely, the role of poets in the educational model, which is a disputed issue between the Platonic Academic and the Aristotelian Lyceum. For Plato, it is necessary to expel poets from Polís, as their work is nothing but lies and irrational thinking, even though they act under divine inspiration, pretending to be mediators between gods and men (Politheia X, 607b, 6-7; Ion, 533de-534ab; 535e-536a; 531d). This kind of hermeneutic of myths influences Enlightenment historiography in radically dissociating religion and science.

However, for Aristotle, following the intuitions of poets, from the Odyssey to the tragedies, "the lover of myth (philomythos) is, in a sense, a lover of Wisdom (philosophia), due to the wonder (dia tu thaumasein) that myth awakens in the amazed one, the one who contemplates them (Metaphysics I, ii, 982b, 19). For the Stagirite, the 5th century theoretical ideal was also present in the poets who composed the myths. Indeed, the word theater derives from the verb theáomai (to look, to contemplate, to admire), and the one who participates in the theater is theorós (spectator), from which the exercise of contemplating or theorizing (theoria) derives. In Poetics, Aristotle revisits the tragedy and its philosophical potential for representing reality, awakening to the perception of causal relationships and purifying the soul's feelings. There is an ontology of health in medicinal myths that propose a cure of the culture. There was a nootherapy as a metanoia, changing the mind and transforming feelings (katarsis), changing the patient's attitude toward not only the disease, but life.

If there is a change regarding the interpretation of tragic myths influencing the Stoics, thinking about them from the political reality of the people (demos) and incorporating the Hippocratic vocabulary (Dumortier 1975), there is a relationship between Stoic spirituality and the Hippocratic spirituality of relating awareness of the problem and its rational discernment. The myths in the Hippocratic Oath 
can be interpreted as poetic wisdom that converges for the exercise of intellectual apprehension of reality, a source of hope, since the poetics of myths awaken to the search for theory (theoria) and to the enthusiasm for duty (enthéos) and action (praxis), which are indispensable dimensions to face the pandemic challenge. This is why there is an amphitheater in Asclepeion, a fundamental element in nootherapy, including in the asclepiad treatment festivals of theater, dance, music, and singing to transform and heal thoughts and feelings.

\subsection{Healing Deities of the Hippocratic Oath}

When thinking about the Hippocratic myths as askésis, it is possible to highlight the spiritual meaning in the search for ideal health and to identify some traits in the evolution from the asclepiad rites to clinical practices in the School of Kos, specifically when exploring the semantic development of the four healing deities of the Hippocratic oath, Apollo, Asclepius, Higyeia, and Panacea. In these myths, the wisdom that guided Ulysses home are present, which now guides the physician priests to face the challenge of the epidemic.

Among the four deities mentioned in the Hippocratic orkós, Apollo is the most important. However, this deity undergoes profound cultural and theological transformations. In The Iliad, Apollo was just a "god of sanctuary" and a "provincial deity" (Brandão 2013, v. I, pp. 143-44). Apollo's change of status indicates a "long evolution of Greek culture and spirit" and consequently a theological shift amalgamating several mythical functions of other deities. For example, Apollo takes the place of Helios and becomes the "god of light", "ideal of culture and wisdom", and "the creator of the balance and harmony of desires", redirecting them toward a "progressive spiritualization" that culminates in the "development of consciousness" based on the couplet "know yourself" (gnothi s'autón) of Delphi's Oracle (Brandão 2013, v. II, p. 86), the [mythical] center of the Greek world, the Greek Jerusalem, set by divinity. Apollo was considered by Plato as key to reading Homeric myths. He actually called him a "national exegete" (patrios eksegétes), as "it is Apollo, the god of Delphi, that competes to establish as more important laws, as more beautiful and the first among all" (Politheia 427, bc). He is essentially a reconciling deity, who aims to unite the contrasts of the polis through wisdom (sophrosyne). Thus, it must be assumed that the Hippocratic Oath's mention of Apollo (460-377/70 BC) refers not to the Homeric provincial deity, but to this one from Plato's time (428/27 to 348/47 BC), and therefore, he is invoked as a god who grants light and inspires wisdom. Despite Apollo's semantic displacement, a trait remains from Homer to Delphi, that is, he is a healing god, as indicated by the epithet dedicated to him in The Iliad, the Paiéon, possibly of Minoan origin and which will be considered a healing song: "Paiéon/in a beneficial balm [phármaca] bathed his wound/and healed him [katathetós], as he was not of a deadly strain" (V.401-402). Given the semantic dislocation, the remedy [phármacon] of the Hippocratic Apollo and his cure [katathetós] are linked to the "self knowledge" that cleanses the soul of ignorance.

Asclepius was a doctor who "is worth for many men" (Iliad XI, 514-515). He had visited Troya with his two sons, Podalírio and Macaon, and a friend of Achilles, Patroclo (Iliad, 729-732). At some point, he starts to be portrayed as a hero, the son of Apollo and with a mortal mother named Coronis. Coronis, fearing Apollo's infidelity, joins another mortal, Ischia, and both end up being killed according to Apollo's wishes. Her son, Asclepius, has been born by an "umbilical cesarean section" and been educated by Kheiron, which is possibly a name made from the abbreviation kheirour-gós, meaning the one who "works with his hands", a "surgeon". Kheiron himself had two significant notes: he was a wounded doctor and a Centaur. In the massacre of the Centaurs, he was wounded by Heracles with an arrow, causing an incurable wound, and consequently, since he was the son of Cronos, eternal immortality. This condition of a wounded doctor helped him to understand his patients with compassion. In an exchange with Prometheus, who grants him the right to death, Kheiron ascends to heaven and his ascension, as animal and man, can be considered the synthesis of the human who develops spiritually. Asclepius learned from Kheiron features such as friendship with men, music, morals, and especially medicine, perfecting it to such an extent that he learned how to raise the dead. This specific detail is why Zeus struck him at Pluto's request. Foremost, due to his immense 
importance, he had been deified. From an expert doctor, he becomes a hero (Apollonius of Rhodes 1912, Argonautica) and then the myth of the "philanthropist" medical god, for giving life back to those already considered dead. Of his four children, only his daughters, Panaceia and Higyeia, are mentioned in the Oath. Asclepian theogony, as mitopoiesis of the gods, indicates in his divinity's modus vivendi that evokes the search for healing all diseases [Panacea] and not only the fact of health. The health value [Higyeia] must be worshiped but also to transform the meaning of worship into practices that favor the rehabilitation of human nature. Myths support rites, which aim for action corresponding to the myth and suggest a lifestyle to the sick. Thus, the rites were aimed at what the myth evoked: healing. When entering Asclepeion, the sick take part in religious rituals, including fasts, diets, baths, and anointings (Higyeia's rites). After that, the sick should rest in the Abaton and even stay overnight, to collect their dream report. Asclepiads visited the sick daily, and recorded in the tholos, a circular building where the name of the healed sick was inscribed, the diseases that had come to the temple and how the patient had been treated (Daremberg and Saglio 1892). Based on descriptions of dreams, symptoms, changes in vital signs, and weight, Asclepiads prescribed potions for bleeding, hemlock, vomiting, and purgatory (Koch 2012, pp. 23-27).

In addition to the semantic shift from legend to myth, there is also a change in healing practices to the proposition of a way of life: health is conceived as a cultural value, and consequently, the Hellenic ideal of a healthy human being is engendered there. The patient's attitude was mirrored by the doctor, who himself practices the way of life prescribed. Hence, should the physician of Kos swear: "With holiness [agíos] and purity [osíos] I will preserve my life and my art" (Orkós, 4). The Hippocratic Oath is key to reading the "holy thoughts" prescribed to the sanctuary's faithful sick, the ones who believed in Panacea and Higyeia-that is, in the cure of all diseases and in the creation of a culture that promotes values of health, the kind of faith that is reflected in the attitude of coping with the disease.

The Enlightenment historiography tends to accentuate Hippocrates' contact with Ionian science and how it impacted the Hippocratic method (Frias 2005, pp. 23-31). However, it does not necessarily exclude Hippocrates' identity as an asclepiad, as attested to by his contemporaries. The Enlightenment dichotomy makes it difficult to perceive the Hippocratic synthesis between philosophy and spirituality or the search for a principle of action in nature [arché] and faith in human nature. This perspective, aside from being a rupture, elaborates a new soteriology and constitutes a theological advancement (Ferry 2006, p. 28). The world order maintained by Zeus and his pantheon is reread as the beauty of the Cosmos in which reverence for the gods [theoi] shifts to contemplation of the mystery of the universe's beauty, which is all interrelated with everyday life. In this way, contemplation [theoria] aims to find cause and effect correlations and reproduce the universe's beauty as a macrocosm in the microcosm of life. Furthermore, the physician's ethical stance did not come from an understanding of natural law (nomos physis) and even endorses slavery (Politics I. 5.1254a, 14-18), but then from the asclepiad concept of sanctity, the idea that the treatment of people should be done with equality of "free and slaves" (Orkós 2). It unfolds from the myths of Asclepius' philanthropy, as well as the discernment to avoid evil and injustice, to keep their secrets, even with those slaves who, together with women, were had for nothing (Orkós 6; 7).

The preparation of literature for a lay population, the precursor to preventive medicine, can be seen in the same perspective. Undoubtedly, Ionian philosophy offers the possibility of a "directed look" at clinical observation, making it possible to treat diseases as being of human origin and not divine. Still, it does not, in any way, require the refusal of an asclepiad theology, but rather, it results in a way from thinking about health from a theological consciousness that affirms faith in life, and the hope of being able to get a little closer to a utopia of healing for all diseases (Panacea), especially after the Athenian epidemic. A challenge that required scientific investigation, but also a pact between the patient and the physician, establishes the value of health (Higyeia) as a new way of life. The prestige of the Kos, Epidaurus, and Pergamum sanctuaries indicates the occurrence of a cultural revolution through the combination of Asclepiad communities and the Hippocratic method, especially when these sanctuaries were declared Panhellenic and received diplomatic immunity respected by all Greek 
nations, which protected them from attacks in times of war (De Mattia 2012). The expansion of the Kos Shrine model, which functions as a hospital, indicates the success not only of the technique but of a new spirituality capable of integrating science to promote the construction of hope (Martzavou 2012).

The third lesson of ancient wisdom learned from epidemic events is the revelation about the human condition. First, it ends crisis, as happened in Athens with its civic religion and democracy infested with oligarchic interests. Second, it reveals the human capacity to reinvent itself and overcome limits that threaten human life. So, it's how asclepiad spirituality and the emergence of medical science ensued. Such a capacity to overcome is in line with the need for greater critical and ethical awareness. In this sense, COVID-19 can be used as a valuable lesson in what needs to be abandoned, including the political and religious perspectives that do not reliably favor consciousness and promote hope. Those factors are fundamental for social and cultural adherence to the process of overcoming (Velosa et al. 2017). In other words, a moment of ethical culture review should take place to determine what is worthwhile as a dimension that humanizes the human. What is understood as unnecessary does not require a big show for its expulsion, it should simply be left out in a slow process of silent cultural revolution that stops believing in some things and starts betting on others.

\section{The Christian Reception of Hippocratic Thought}

Hippocrates' reception in Christianity is not consensual. Hippocratic medicine's reception occurs according to the refusal or assimilation of Greek paideia, consequently, between a view of Christianity as a superior culture, or as an alternative culture, as we prefer here, in which the great ideals are realized by Christian culture (Ferngren 2009, pp. 29-57; Jaeger 2013, pp. 9-22). As a result, this reception has undergone interpretations as convergence positions (Verhey 1984, pp. 157-70) or incompatibility (Veatch and Mason 1987). For example, Tertullian sees Hippocrates as a representative of the Greek school of thought and not just a physician. Thus, despite having an ethical conscience, the Greek physician was not considered by the monk as superior to Christian ethics. Due to the position that does not exempt a Platonizing influence of Christianity (Frias 2005, pp. 79-83), they saw themselves as "doctors of souls", and not only of bodies (Veatch and Mason 1987, p. 88). Even more vehement, Lactantius' criticism presents Asclepius as an "archedaimon" (Divinae institutiones, 2.16.12), revealing Asclepius' influence in the ancient world. Jerome also ridicules the Asclepius priests for not healing from sins, which heals the body, but the pain remains. Therefore, verus medicus or medicus et medicamentum is the holiness of Christ and not the holiness of Hippocrates (Arbesmann 1954, p. 6). The climax of hostility occurs with Constantine's act to eliminate the Asclepiad from a Cilicia sanctuary, as reported by Eusebius of Caesarea, who extolls the elimination of what he calls the remains of the "old madness" (Eusebius of Caesarea 1999, Life of Constantine 3, 56).

The criticism of the rhetorician Arnobius of Sicca in the 4th century is also known, with the defense of Christianity to the Bishop of Sicca as proof of his sincere conversion. In this work, he draws up a kind of thaumaturgical dispute between Christ and Asclepius in order to present the compassion of Christ for all those who suffer, and the greatest number of miracles as distinctive from the pagan god healings. In addition, he criticizes the healing of Asclepius to be reductive to the body, with the remains of the disease on the soul (Adversius nationes, 7, 44). Although, after explaining his view of Christ's superiority, he recognizes medicine as a gift from God and appropriate for Christians and points to the Hippocratic diagnosis of disease attributed to natural and not divine causes (Ferngren 2009, pp. 44-51).

Part of this perspective of incompatibility with Christianity may be the result of persecutions suffered by some Roman emperors. Such unsuitability easily evolves into rivalry in the wake of an epidemic in Alexandria in $252 \mathrm{AD}$. Eusebius of Cesarea presents a letter from Dionysus, bishop of Alexandria (248-264 BC), telling him how the epidemic affected everyone, Christians and pagans. However, says the bishop, these two groups' behavior was opposite. The so-called "pagans" not only expelled Christians from the city but also expelled those who started to get sick, even family members. Even corpses were thrown into the street. All these actions were ineffective to avoid contagion. Despite the apologetic tone in relation to the supposed superiority of Christianity, Eusebius indicates 
some elements of Christian spirituality at the time of the epidemic, namely the understanding of the disease's non-divine origin and the demand of an exercise (gimnásios) of disinterest and fraternity (agapen kai philadelphian) toward those who mistreat them. The infected is the sick brother and demands to be cared for as Christ himself (therapeountes en Christo) (Historia ecclesiastica VII, 22.6-7). The theological formula in Christ evokes the participation in the mystery of the passion, death, and resurrection, and therefore, an itinerary of hope that the agaphic gestures are not in vain, but express the Christian God's will to love his neighbor as himself and thus find God.

Hippocratic medicine's contribution to analyzing the disease's natural causes is irrefutable, placing into dispute regarding which spirituality will prevail in Greek paideia. Other Christian authors did not demonize Greeks. Origen sees in Greek medicine the "clearest parable of the Gospel in action" (Dönermann 2003, pp. 80-84, 121-59). Efrem, the Syrian, presents Paradise as the "medicine of life" as opposed to the "poison of death" presented by the Serpent, which some tried to link to the asclepiad cult. Hence, there seems to be no problem in using terms from Asclepiad theology, such as therapeuo or iaomai (Shemunkasho 2004, p. 15).

Indeed, insofar as Greek myths were reread from the conception of mysteria of Early Christianity (Rahner 1954, pp. 16-59), devotion to Asclepius was replaced by the theme of Christós Iatrós or Christus medicus, already present in Ignatius of Antioch (Eph. 7, 2). Consequently, the epithet of asclepiad soter is also transferred to Christ as in Clement of Alexandria (Stromata I, 75,2). Augustine also uses the category Christus medicus, a strong devotion in Africa since Tertullian, in his soteriology as a redemption metaphor (Arbesmann 1954, pp. 1-28). Augustine does not despise profane wisdom, knowing that "where to find the truth, it is your Lord's thing" (Doctrina Christiana 18); instead, the philosopher of Hippo sorts out a contrasting perspective between both images of Asclepius and Christ. The Cristo magister humilitatis is also medicus humilis (Augutinus 2000, cf. Sermones, 22.1), and the humility of Christ the Saviour stands in opposition to the inability of the Divine Physician, Asclepius [Soter], to cure the Greek culture of the hybris disease that resulted in greed and led to the corruption of virtues. The Greek disease, in its blindness, fails to even see humility as a virtue (Augutinus 2000, cf. Civitas Dei, XIV-XVIII; XXVIII). The assimilation of Asclepius's soter epithet to Christus medicus goes through the same process of amalgam as the Helios myth, with the new Sun (Knipp 1998, pp. 3-22; Daremberg and Saglio 1892, pp. 470-72) assimilating not only an idea, but a soteriology and medicinal-pharmacological iconography (Herzog 1994, p. 434).

Meanwhile, the best Christian School of theology to establish a dialogue with the Greek paideia was the Caledonians. Saint Basil of Caesarea, in his work (Basil of Caesarea 2018) entitled Address to Young Men On Greek Literature (Pros tous neous, ópos an ex hellenikon ofelointo logon), evokes the need of discernment (sinoronta) by one self (par eautou), citing several Greek authors and showing how the Greek theoria and the Evangelical theoria aim for the same end (télos): human excellence as a lifestyle (VII, 1-5). Basil uses bee images to illustrate the discernment exercise of looking for God in all things, especially in the Classics:

"For just as bees know how to extract honey from flowers, which to men are agreeable only for their fragrance and color, even so here also those who look for something more than pleasure and enjoyment in such writers may derive profit for their souls. Now, then, altogether after the manner of bees must we use these writings, for the bees do not visit all the flowers without discrimination, nor indeed do they seek to carry away entire those upon which they light, but rather, having taken so much as is adapted to their needs, they let the rest go. So, we, if wise, shall take from heathen books whatever befits us and is allied to the truth, and shall pass over the rest". (IV, 9)

Basil's work influenced the Byzantine Christian culture not only to read the classics, including in Christian schools, just as it was a key work for the rediscovery of those classics by the Renaissance in the 15th century (Moffatt 1972, p. 74). Indeed, the reception of the classics takes place in a dialogue between the two theologies of health: the Greek and the biblical. There is certainly a theology of health 
in Hebrew Scriptures, with the word shalom containing the concepts of health and peace in its semantic density. Peace is the result of a healthy life, which coincides with the search for a way of fair living. When the heart returns to justice, it brings health and peace to people: "For I will restore your health and heal your wounds, says the Lord" (Jer 30, 17). He who seeks justice finds the "health of peace": "Behold, I will bring health and healing to it, and I will heal them, and they will manifest a source of peace and truth" (Jer 33, 6), and therefore, "the tongue of the wise is health" (Pr 12, 18). Syriac wisdom constitutes an advance in Hebrew health theology $(E x 12,12)$ in its contact in exile with Hellenism, in which the cure comes from God, but through his agent, the physician (Sir 38, 1-5). The Sadducee theocracy and the theodicy of the pure represent a setback in post-exile Judaism, in which the disease is seen as the origin of sin, causing social exclusion. A self-sufficient mentality is often the reason for failure and suffering. The conversion as a way to "return to health" sometimes matches "to live despite" with the invitation to "Take up your cross and follow me" (Mc 10, 21; Mt 10, 28) directly linked to the "path of happiness" [Happy are that... cf. Mt 5-8].

Jesus also "healed those in need of healing", and he also "spoke of the Kingdom of God" for them. The cure came in the desire to follow $(\operatorname{Lk} 9,11)$ and is manifested in the "health of the whole" [holo-klérian] (Ac 3, 16). This aspect coincides with Plato's reading of holos as a method of Hippocrates, as one cannot heal parts without understanding health as the "whole". Once more, the whole [holos] is seen through the harmonious relationship between the microcosm of the soul and macrocosm of the universe (Phaedro, 268e). Herewith, Lucas indicates a cure for the person, the discovery of a greater meaning for life, despite the illness, as with the conversion of Paul (Acts 9: 1-19 cf. Biblia Sacra 1993). Indeed, while health theology is housed in a wisdom of life, New Testament theology is much closer to Asclepiad theology than to Pharisaic theodicy.

The consolidation of Hippocrates' reception and what further became known as Christian physicians [christilichen Ärzten] starts with Lucas, the evangelist; followed by Alexandre's physician, Frigio (177); the Christian school of Galena medicine in Rome (cc. 200); Proculus, a kind of Christian healer mentioned by Tertullian; African Julio (cc 225); Epifanios, a Palestinian doctor and bishop (cc 300); Basilio de Ancira, Aécius, the Aryan, Aglaofon, and Parata (cc. 300); Zenobios of Sidon, a priest and doctor who suffered the martyrdom of Diocletian (303); Theodotus, a physician and bishop of Laodicea (cc 305); Flavius, a grammarian and medical writer; Hierakas, an Egyptian monk and physician (both cc 305); and Eusebius, a physician and bishop of Rome (cc 310). Harnack gives special attention to the medical brothers, Cosme and Damian, patrons of physicians and pharmacists, who studied medicine in Syria and died as martyrs. He also mentions the great Syrian Christian physician in the 9th century in Baghdad, Abu Zaid Honain ben Ishaq (Harnack 1892, pp. 38-50). Despite all the theologians' efforts to dialogue between spirituality and science in a lucid and responsible way regarding health, the production of theodicy is a constant religious temptation. However, the dialogue between spirituality and health is an important instrument to face this type of religious mentality. It can effectively denounce religious affirmations to underpin political intentions on the evasion of public health responsibility. The very notion of public health responsibility that emerges from the awareness of universal brotherhood is the Christian form par excellence of confronting theodicy, even once raised inside Christianity.

At the same time in which the Portuguese playwright Gil Vicente condemned the theodicy of some friars who preached the tolerance of Christians toward Jews as the cause of the 1531 Lisbon Earthquake, resulting in their massacre (Bandera 2010, pp. 44-45), the Society of Jesus' Constitution, written in 1540 (Inácio de Loyola 2004) by Saint Ignatius of Loyola (1491-1556) began to move in the opposite direction. The Constitutions thus presented a very distinct embryonic health theology for modern times. In Ignatius' spirituality, or more precisely in his Spiritual Exercises, there emerges a Christian concept of the cure of freedom, and concomitantly, the cure of the community takes place through participation in the healing process. Thus, despite the remains of the 16th century theodicy language, the conception of and the importance given to health have no connection to the origin of illness or the idea that health comes from God, but it is the health of a whole (body and soul and the 
community) that glorifies God. It is a shared responsibility, with four subjects of action listed in the Constitution: the individual, the community's superior, the doctor, and the community.

The individual is invited to see health as a gift from God and taking care of the body as their first responsibility. It is even a spiritual task, which must:

"to make progress and advance in spirit and virtue on the path of divine service, looking at the health and bodily strength required to work in the Lord's vineyard. So, it will be first of all what concerns the spirit, and then what concerns the body. (Chapter I, Conservation of the Soul and Progress in the Virtues" [243] 1)

Therefore, the person must know how to measure care for spiritual things and care for the body, paying attention to any signs of dysfunction:

"Although the exaggerated concern with body care is reprehensible, due care in using the means of preserving health and physical strength, for divine service, is to be praised and asked of all. Therefore, when they feel that something is bad for them, or that something else is needed, regarding food, clothing, housing, office or work, as well as anything else, they must warn the Superior". (Chapter II, Conservation of the body [292] 1)

This leads to a positive aspect in how "some bodily exercise for the benefit of both is ordinarily useful for everyone, even for those who must apply themselves to intellectual work" ([298] 4). Likewise, one should moderate penances as it does not harm their health and continues to observe medical recommendations in general, such as respecting "the sleep time, [which] it seems, should generally be six to seven hours" ([301]). The responsibility to one's own health is God's will, "so that Our Lord God may be more glorified in our souls and our bodies" ([300] 5).

Then, it is the superior's responsibility, as an authority with the role of helping to discern the will of God, "defending the health" of community members ([424] 5) through ensuring the presence of someone with "superintendence of everything it concerns health to help preserve it in those who have it" and "restore it to those who are sick" ([303] 6). For this reason, "it is good not to burden anyone with so much physical work that the spirit is drowned, and the body is harmed" ([298] 4). The superior is also responsible for ensuring that health is seen as a necessary feature of the mission, and if a newcomer is not healthy enough to be able to "face the demands "of the mission, the person "could be dismissed, but with due charity". The ruling goes on to say, "after the first votes and before the last" no one can be dismissed "even for lack of physical or mental health if the illness was contracted due to the Society's carelessness or due to the work done in it". Even though the sick must be seen by the community as a gift and welcomed [34, 1st and 2nd].

The responsibility for health, which is ultimately God's will, is shared by doctors and nurses who, on the occasion of a patient in the community, become something similar to a house superior, and must be obeyed as the very voice of God:

"When someone is sick, obedience must be kept with great purity, not only to spiritual Superiors to direct the soul, but also, with the same humility, to body doctors and nurses, so that they can look after the body. For the former deal with the full health of the soul, and the latter with the perfect health of the body'. ([89] 32)

Finally, as being of special importance, the community, which in addition to sharing the duty to help "look for the conservation of the health of each one" ([826] 13), must be aware of its calls for deprivation, for "not everyone has the same natural strengths, [and] not everyone has the same physical health" (Chapter II, Poverty and its consequences [579] M). Consequently, the disease becomes an invitation to the community to host a sick member and to cooperate with God in their fight for health, so everyone should have life in common. When someone needs greater care, to give this person more than others "for lack of health", "is in no way opposed to ordinary life" (Article III, on ordinary 
life, 174,1 st). If even all preventive care is taken and the disease overcomes the sick anyway, it must continue to be seen as an invitation to all to become agents of health, each in their own way, and at the same time, it is regarded as a phenomenon that calls for a review of the meaning of existence, rethinking the way of living. In other words, once it is impossible to cure a specific disease, one must seek a cure by curing the relationships involved. Here, cure is understood as a resignification of these relationships, until the end of the life of the leaving one. In Ignatian health theology, God acts in this resignification act. God is not at the origin of the disease, but once it has happened, God acts, as Thomas Aquinas would say, in secondary causes (Aquinas 2002, cf. Suma Teológica I, q. 117, ad. 1). In this case:

"The patient must, in addition, show great humility and patience in order not to give those who visit him, and speak and treat with him, less edification during the illness than before when he was healthy, for the greater glory of God". ([89] 32)

Healing takes place at the deepest level when the patient finds new meanings in life, rethinking what led him to the disease and inviting him to find deeper reasons to live. It is a theme already present in Augustine's Christus medicus, with humility [humilitas] as the cure for illusion of self-sufficiency, that is, the problem of Greek hybris. There is a cure for freedom as a willingness to take responsibility for health, as it further raises the consciousness of accountability. However, it must be considered that certain diseases are not the cause of the patient's edification, such as when the disease leads to "losing the use of reason", in which "there is no guilt or merit for what they say", or when "Some sick person is not as uplifting in his illness as he would like". In this case, the community heals when it responds to the call to give special care to a sick person or, to put it another way, the community healing happens in the way in which it starts to be connected with the patient's resignification. Despite medical care, other community members must visit the patient, catalyzing the resignification, either by the patient, who must learn to live despite the disease (without a cure), or most of the time, by the community, which learns to live with the disease.

Just as the disease affects the community, the cure is also the community's overcoming the disease, or discovering a new way of living. This posture has led to the creation of health centers to better serve these patients, which are supported by the community's work ([597]). The patient is Christ who suffers, and the community is called to be Christus medicus. The hospital is connected to the experience of giving back a sense of human reality, and consequently, of humility as a cure for narcissism.

Two other lessons can be learned from the ancients' wisdom and applied in the time of COVID-19. The fourth lesson regards how health, or a disease, is experienced in the human condition that life is capable of meaning, despite its absurdities, including the absurd disease, in order to boost hope and coping. The disease is not the end of life, but a new beginning, and perhaps the end of a phase. Here, health is thought of as part of a spiritual process, which is understood as a search for meaning in life. Healthy living is closer to "a meaningful existence and a life that is worth living" (Esperandio and Ladd 2015, p. 677) than a healthy physiological organism with no greater purpose for living. A meaningful life can be lived in spite of illness.

Hence, the period of life without a vaccine to cure COVID-19 demands another way of conceiving of health, so society can continue living despite the disease or until its eradication. The awareness that life can have meaning despite its countless absurdities is a source of serenity and resilience in facing the challenges that we face, and the dialogue with spirituality can be a rich source to strengthen our ways of coping with the pandemic.

The fifth lesson drawn from the pandemic regards the relationship between spirituality and health if the epidemic were to be considered a disease of the city. The protagonist for the cure is the community, or more precisely, the society acting in a community spirit. The dimension of this community root lies on the one hand in the spirituality of universal brotherhood and, on the other hand, in the condition of common dignity. Such dignity is seen as a gift and a task, as it requires effective efforts with regard to public policies to guarantee the minimum necessary for a dignified life, as well as demanding a 
production of culture that expands this perspective for practices of deep humanization. The current pandemic moment reveals the institutional fragility with which human dignity is treated in the 21st century. As Pope Francis says:

Aside from the different ways that various countries responded to the crisis, their inability to work together became quite evident. For all our hyper-connectivity, we witnessed a fragmentation that made it more difficult to resolve problems that affect us all. Anyone who thinks that the only lesson to be learned was the need to improve what we were already doing, or to refine existing systems and regulations, is denying reality. (Francis 2020, cf. Fratelli Tutti 7)

\section{Conclusions}

Disease is not only a biological phenomenon but an existential one, in terms of how the sick participate in the cultural and historical experience of a certain region and time, assimilate the cultural meanings (passive sense), and elaborate new ones (active sense) as conscious, at least, of the new condition being experienced. Thus, disease is an event that requires discerning action for the cure. Among these passive culture meanings, there is the challenge of overcoming forms of theodicy. These kinds of religious mentality work as an anesthesia of responsibility and elaborate meanings that generate proactive attitudes. Once forms of theodicy are overcome, the wisdom present in health theologies can be constituted as cooperative types of medical and therapeutic treatments, as well as the resilience of a lucid spirituality in dialogue with science. In the inexhaustible mission of health theologies overcoming forms of theodicy and promoting cooperative spiritualities lies the origin of Western medicine itself, namely the asclepiads experience and its best-known member, Hippocrates of Kos.

The experience of the Athens epidemic imposed challenges that reveal its political dimension, requiring cooperative efforts from different spheres and indicating how public health can be seen as an element of cultural unity and social cohesion. When unity fails, it can result in a catastrophe of even bigger proportions. Therefore, the epidemic poses a greater challenge than the clinical one, as a change in mentality is required to combat its progress. The asclepiad spirituality was of fundamental importance for the consolidation of a paideia, establishing a new relationship between nature and culture and providing a source of hope in the centuries following the terrible Athenian episode. This spirituality shifts the understanding of disease from divine causes to natural causes and reallocates the wisdom of myths in practices of care. It also produces a new horizon of meaning in which the presence of a divine mystery works on the health agent to expand the limits of knowledge of the diseases (panacea). Hippocratic medicine is a tekné, which is a word that is also used in poetry, and it includes technical ingenuity and divine inspiration to reinvent consciousness. In the Hippocratic case, these poiesis happen in the form of nootherapy and the accumulation of knowledge that enables new practices. The Asclepiad gods in the Hippocratic oath could be synthesized as a kind of creed based on the unity between the wisdom of culture (Apollo), medical knowledge (Asclepius), and a spirituality that feeds reason for hope (Panaceia) to approach the horizon of meaning of a healthier humanity (Higyeia).

It is precisely the spiritual dimension in Kos asclepiad medicine that leads to its success and is responsible for the expansion of asclepiad sanctuaries acting as hospitals. It is also the conflicting element with Christianity in the dispute of who would occupy the central role in Greek paideia. Regarding the technical knowledge (tekné) of medicine, Hippocrates alters the religious culture of the Hellenic world, understanding medicine as a gift from God to serve humanity. Despite the differences between Hellenism and Christianity, this aspect remains.

Even considering their differences, both the figure of Asclepius Soter and Christus medicus raise awareness of the cultural cure, while healing the way of seeing health and disease. In asclepiad nootherapy, the doctor who places faith in life is also a priest of hope, who proposes "holy thoughts" - that is, a lifestyle that promotes a greater meaning. In Ignatius of Loyola's conception 
of health, the disease has no origin in God; rather, it is an event in which there is a call from God to responsibility, and consequently, a cure can also occur in the community beyond the sick. The search for meaning in health theologies apprehends a "health model" based on a theological consciousness, carried out in the perception of "divine pedagogy" (Álvarez 2013, p. 104). In this sense, Christian theology has always emphasized the importance of public health from a perspective of universal brotherhood, that is, the community awareness of responsibility for the health of everyone. The provision of health care for all is an aspect that converges with Hippocrates' view ("as many houses as I enter, I will enter for the benefit of those who suffer [ ... ] women, free men or slaves" cf. Orkhós, 6), and with the Evangelical perspective (I was sick and you visited me, cf. Mathew 25, 36).

Health theologies have a primary role in confronting the fanaticism and fundamentalism associated with diseases and episodes that threaten public health such as epidemic or pandemic events. In addition, in a purposeful sense, they could provide deeper reasons to dynamize the performance of health professionals and promote a healing of culture that involves societal responsibly in the valuing of health. Here lies the purpose of public health theologies: to affirm that religious faith is also faith in life, promoting interculturality with the scientific community to solidify the hope for an ideal health of humanity.

The ancient wisdom lessons in health spirituality can be very timely in helping people to live despite the COVID-19 pandemic. At the same time, such spirituality also reveals the political dimension of the pandemic, in terms of revealing health as a public value, due to its origin in universal human dignity. Health should not be seen as a product to be traded on the stock market, receiving investments only when profitable. The pandemic also reveals the political health of democracies. It is important to consolidate the memory of this moment for years to come, just as Thucydides did in relation to the oligarchic disease of Athenian democracy. The issue here is reversed as the pandemic becomes the symptom of diseases of the political, social, and economic systems in this time of COVID-19 with the lack of a vaccine, except the change in mentality that life always comes first of all. It requires a cultural and social unit capable of integrating differences around this fundamental health value to face the political and financial opportunism that makes democracy sick. The academic community has a special responsibility in this matter as a service to ordinary people.

Funding: This research received external funding from FCT—Fundação para a Ciência e a Tecnologia, Portugal Government.

Conflicts of Interest: The author declares no conflict of interest.

\section{References}

Álvarez, Francisco. 2013. Teologia da Saúde. São Paulo: C. U. São Camilo/Paulinas.

Apollonius of Rhodes. 1912. The Argonautica. Edited by George W. Mooney. London: Longmans, Green.

Aquinas, Thomas. 2002. Suma Teológica. v.1, Parte 1. São Paulo: Loyola.

Arbesmann, Rudolph. 1954. The Concept of Christus Medicus in St. Augustine. In Traditio: Studies in Ancient and Medieval History, Thought, and Religion, v. 10. New York: Fordham University, pp. 1-28.

Aristotle. 1984. The Complete Aristotle. Princeton: Princeton UP, vol. 2.

Aristophanes. 1907. Aristophanes Comoediae. Edited by Frederick W. Hall and William M. Geldart. Oxford: Clarendon Press, vols. 1-2.

Augutinus, Aurelius. 2000. Opera Omnia. Nuova Biblioteca Agostiniana. Roma: Città Nuova Editrice.

Aurelius, Marcus. 1908. Ad Se Ipsum. In Aedibus B. G.. Edited by Jan Hendrik Leopold. Leipzig: Teubneri.

Bandera, Cesareo. 2010. Sacred Game: The Role of the Sacred in the Genesis of Modern Literary Fiction. University Park: Penn State Press.

Basil of Caesarea. 1926. Saint Basil the Letters, in Four Volumes. Edited by Roy J. Deferrari. London: William Heinemann, New York: G. P. Putnam's Sons.

Basil of Caesarea. 2018. Aos Jovens Sobre Como Tirar Proveito da Literatura. Texto Bilingue. Translated by Miguel Cabedo e Vasconcelos. Lisboa: Universidade Católica Editora.

Biblia Sacra. 1993. Utriusque Testamenti. Edited by Hebraica et Graeca. Sttutgart: Deutsche Bibelgeselschaft. 
Brandão, Junito. 2013. Mitologia Grega, v.1 e 2, 25th ed. Petrópolis: Vozes.

Burford, Alison. 1969. The Greek Temple Builders at Epidaurus: A Social and Economic Study of Building in the Asklepian Sanctuary, during the Fourth and Early Third Centuries B.C. Liverpool: Liverpool University Press.

Cairus, Henrique F., and Wilson A. Ribeiro Jr. 2005. Textos Hipocráticos: O Doente, o Médico e a Doença. Textos Hipocráticos: O Doente, o Médico e a Doença. Rio de Janeiro: Editora FIOCRUZ.

Cornutus, Lucius Annaeus. 2018. Theologiae Graecae Compendium. In Fragments and Testimonia. Atlanta: SBL Press.

Daremberg, Charles, and Edmond Saglio. 1892. Dictionnaire des Antiquités Grecques et Romaines, Verbete Asklépion, v.1. Paris: Hachette, pp. $470-72$.

De Mattia, D. 2012. Il Tempio Romano dell'Asklepieion di Kos: Nuovi Dati per la Sua Anastilosi. Oxford: Thiasos, pp. 61-80.

Diderot, Denis. 2020. Obras VI-O Enciclopedista_Vol. 2. Edited by Jacob Guinsburg and Roberto Romano. São Paulo: Editora Perspectiva.

Dillon, Matthew P. J. 1994. The Didactic Nature of the Epidaurian Iamata. Zeitschrift für Papyrologie und Epigraphik 101: 239-60.

Dönermann, M. 2003. Krankheit und Heilung in der Theologie der fhühen Kircheväter. Tübingen: Mohr Siebeck.

Dumortier, Jean. 1975. Le vocabulaire médical d'Eschyle et les écrits hippocratiques. Paris: Société d'édition Les Belles Lettres.

Esperandio, Mary Rute, and Kevin Ladd. 2015. I Heard the Voice. I Felt the Presence: Prayer, Health and Implications for Clinical Practice. Religions 6: 670-85. [CrossRef]

Eusebius of Caesarea. 1926-1932. The Ecclesiastical History. Translated by Kirsopp Lake, J. E. L. Oulton, and H. J. Lawlor. London: William Heinemann, New York: G.P. Putnam's Press, Cambridge: Harvard University Press, vols. 1-2.

Eusebius of Caesarea. 1999. Life of Constantine. Edited by Averil Cameron and Stuart G. Hall. Oxford: Clarendon Press.

Ferngren, Gary B. 2009. Medicine and Health Care in Early Christianism. Baltimore: John Hopkins University Press. Ferry, Luc. 2006. Aprender a Viver: Filosofia para os Novos Tempos. Rio de Janeiro: Editora Objetiva.

Francis, Pope. 2020. Encyclical Letter Fratelli Tutti, on Fraternity and Social Friendship. Vatican: Libreria Editrice Vaticana. Frias, Ian. 2005. Doença do Corpo, Doença da Alma: Medicina e Filosofia na Grécia Antiga. Rio de Janeiro: Editora PUC, São Paulo: Edições Loyola.

Gramaticos, Philip C., and Aristidis Diamantis. 2008. Useful known and unknown views of the father of modern medicine, Hippocrates and his teacher Democritus. Hellenic Journal of Nuclear Medicine 11: 2-4.

Hadot, Pierre. 2014. Exercícios Espirituais e Filosofia Antiga. Col. Filosofia Atual. São Paulo: É Realizações Editora.

Harnack, Adolph. 1892. Medicinische aus der ältesten Kirchengeschichte. In Texte und Untersuchungen zur Geschichte der Altchristlichen Literatur. Edited by Adolf Harnack and Otto Gerhardt. Leipezig: Hinrich'sche Buchhandlung, pp. 38-50.

Herzog, Markwart. 1994. Christus medicus, apothecarius, samaritanus, balneator. Motive einer medizinischpharmazeutischen Soteriologie. Geist und Leben 67: 414-34.

Homer. 2012a. Ilíada. Texto Bilingue, v.1 e 2. Haroldo de Campos. São Paulo: Editora Benvirá.

Homer. 2012b. Odisseia. Edição Bilingue. Trajano Vieira. São Paulo: Editora, p. 34.

Inácio de Loyola. 2004. Constituições da Companhia De Jesus e Normas Complementares. São Paulo: Edições Loyola. Jaeger, Werner. 2013. Paideia: A Formação do Homem Grego. São Paulo: WWF, pp. 1011-71.

Jones, W. H. S. 1868. Hippocrates Collected Works I. Hippocrates. Cambridge: Harvard University Press.

Kelly, Heath. 2011. The classical definition of a pandemic is not elusive. Bulletin of the World Health Organization 89: 540-41. [CrossRef] [PubMed]

Knipp, David. 1998. Christus Medicus in der Frühchristlichen Sarkophagskulptur_Ikonographische Studien zur Sepulkralkunst des Späten Vierten Jahrhunderts. Brill: Köln, pp. 3-22.

Koch, Scheila Rotondaro. 2012. Os Santuários de Asclépio: Expressões Arquitetônicas, Sociais e Religiosas nos Séculos V, IV e III. Master's dissertation, Programa de Pós-graduação em Arqueologia do Museu de Arqueologia e Etnologia da USP-Universidade de São Paulo, São Paulo, Brazil.

Martzavou, Paraskevi. 2012. Dream, Narrative and the Construction of Hope in the 'Healing Miracles' of Epidauros. In Unveiling Emotions: Sources and Methods for the Study of Emotions in the Greek World. Edited by Angelos Chaniotis. Stuttgart: Franz Steiner Verlag, pp. 177-204. 
Moffatt, Ann. 1972. The Occasion of St. Basil's Address to Young Men. Antichton 6: 74-86. [CrossRef]

Osborne, Robin. 2015. Unity vs. Diversity. In The Oxford Handbook of Ancient Greek Religion. Edited by Esther Eidinow and Julia Kindt. Oxford: Oxford University Press, pp. 11-16.

Pafsaniou. 1898. Description of Greece. Translated by James Frazer. London: Macmillan, vol. 6.

Plato. 1921. Plato in Twelve Volumes. Translated by Harold N. Fowler. Cambridge: Havard UP, London: William Heinermann.

Rahner, Hugo. 1954. Mythes Grecs et Mystére Chrétien. Paris: Payot.

Rosner, Fred, and Sussman Muntner. 1965. The Oath's Asaph. Annals of Internal Medicine 63: 317-20. [CrossRef] [PubMed]

Shemunkasho, Aho. 2004. Healing in the Theology of Saint Ephrem. Piscataway: Gorgias Press.

Sophocles. 1912. Sophocles. Vol 1: Oedipus the king. Oedipus at Colonus. Antigone. Translated by F. Storr. London: William Heinemann Ltd., New York: The Macmillan Company.

Thucydides. 1998. The Peloponnesian War. Translated by Steven Lattimore. Indianapolis: Hackett Press.

Veatch, Robert M. 2000. Cross-Cultural Perspectives in Medical Ethics. London: Jones and Bartlett.

Veatch, Robert M., and Carol G. Mason. 1987. Hippocratic vs. Judeo-Christian Medical Ethics: Principles in Conflict. Journal of Religious Ethics 15: 86-105. [PubMed]

Velosa, Teresa, Silvia Caldeira, and Manuel Luís Capelas. 2017. Depression and Spiritual Distress in Adult Palliative Patients: A Cross-Sectional Study. Religions 8: 156. [CrossRef]

Verhey, A. 1984. The Doctor's Oath: A Christian Swearing it. In Respect and Care in Medical Ethics. Lanham: University Press of America, pp. 151-81.

Walton, Alice. 1894. "The Cult of Asklepios", Cornell Studies in Classical Philology, n. 3. Cornell University. Chicago: Ginn \& Company, p. 136s.

Xenophon. 1970. Xenophontis Opera Omnia. Oxford: Clarendon Press, vol. 4. First published 1910.

Yapijakis, Christos. 2009. Hippocrates of Kos, the Father of Clinical Medicine, and Asclepiades of Bithynia, the Father of Molecular Medicine. In Vivo: International Journal of Experimental and Clinical Pathophysiology and Drug Research 23: 507-14.

Publisher's Note: MDPI stays neutral with regard to jurisdictional claims in published maps and institutional affiliations.

(C) 2020 by the author. Licensee MDPI, Basel, Switzerland. This article is an open access article distributed under the terms and conditions of the Creative Commons Attribution (CC BY) license (http://creativecommons.org/licenses/by/4.0/). 